Original Research Article

\title{
Comparative study of effects of ramosetron and ondansetron on global satisfaction of patients on cisplatin chemotherapy in head and neck cancers
}

\author{
Swapnil Srivastava1, Quazi Shahir Ahmed $^{2 *}$, Kauser Sayedda²
}

\begin{abstract}
${ }^{1}$ Department of Pharmacology,
Hind Institute of Medical

Sciences, Lucknow, Uttar

Pradesh, India

${ }^{2}$ Department of Pharmacology, IIMS and R, Integral University, Lucknow, Uttar Pradesh, India
\end{abstract}

Received: 08 November 2017 Accepted: 12 December 2017

*Correspondence to:

Dr. Quazi Shahir Ahmed, Email: quazi800@yahoo.com

Copyright: (C) the author(s), publisher and licensee Medip Academy. This is an openaccess article distributed under the terms of the Creative Commons Attribution NonCommercial License, which permits unrestricted noncommercial use, distribution, and reproduction in any medium, provided the original work is properly cited.

\begin{abstract}
Background: To compare level of satisfaction of the patients receiving ramosetron and ondansetron in prevention of acute and delayed nausea and vomiting associated with cisplatin chemotherapy.

Methods: 60 patients were recruited in the study. Patients were randomly allocated to ramosetron $(\mathrm{R})$ and ondansetron group $(\mathrm{O})$. Patients were screened between day 1 and day 7. Study visits included clinic visits on day 8 , day 9 and day 14. Patient diaries were used to record patients' global satisfaction which was based on severity of nausea and vomiting using visual analogue scale (VAS), recorded daily until day 12 starting from day 8 . On $14^{\text {th }}$ day the patient diary cards were collected back.

Results: VAS score was significantly lower in R group (46.2 \pm 4.95$)$ as compared to $\mathrm{O}$ group $(63.7 \pm 5.06)(\mathrm{p}<0.01)$ in acute phase of nausea and vomiting indicating level of satisfaction higher in R group. Similarly, in delayed and overall phase R group (49.57 \pm 14.63 and $48.9 \pm 12.91$ respectively) experienced lower range of scoring on VAS scale as compared to $\mathrm{O}$ group (63.0 \pm 8.49 and $63.10 \pm 7.38$ respectively). The difference was statistically significant $(\mathrm{p}<0.01)$.

Conclusions: Level of overall satisfaction of the patients in $\mathrm{R}$ group was significantly higher as compared to $\mathrm{O}$ group in patients receiving the two drugs for prevention of nausea and vomiting caused by cisplatin chemotherapy in head and neck cancer patients.
\end{abstract}

Keywords: Cisplatin, Level of satisfaction, Ondansetron, Ramosetron, VAS

\section{INTRODUCTION}

Chemotherapy can be seen as a life saver for those diagnosed with cancer. Unfortunately, chemotherapy often has side effects. One of them is chemotherapy-induced nausea and vomiting, (CINV). Some chemotherapies cause nausea and vomiting mostly within the first few hours of getting the treatment (acute nausea and vomiting). Others cause acute nausea and vomiting followed by another period of nausea and vomiting a day or more after chemotherapy has been given (delayed nausea and vomiting). ${ }^{1}$ In a study, cancer patients ranked nausea and vomiting as the first and second most severe side effects of chemotherapy, respectively. $^{2}$

CINV continue to remain a concern for patients receiving cancer treatment. It has been observed that the frequency of chemotherapy induced nausea and vomiting, particularly delayed nausea and vomiting, is underestimated by oncology physicians and nurses. ${ }^{3}$

The consequences of not controlling the nausea and vomiting induced by cancer treatment may lead to many complications, a failure of the patient to comply with the 
cancer therapy and follow-up, and a diminished quality of life. $^{4}$

There are a number of drugs that are used to manage nausea and vomiting. These drugs are generally antihistaminic, phenothiazine derivatives, anticholinergics and dopamine receptor antagonist with unwanted side effects like sedation, dysphoria, extrapyramidal symptoms, dry mouth, restlessness and tachycardia. ${ }^{5}$

Recently, introduced selective serotonin 5hydroxytryptamine type $3\left(5-\mathrm{HT}_{3}\right)$ receptor antagonists $(5-$ $\left.\mathrm{HT}_{3} \mathrm{RA}\right)$ are devoid of such side effects and are highly effective and thus the first line therapies in prevention of CINV. ${ }^{6}$

Serotonin antagonists are believed to be effective in acute CINV because serotonin is released rapidly from the enterochromaffin cells in the gastrointestinal tract in the first $24 \mathrm{~h}^{7}$ In humans, a peak in the serotonin metabolite 5-hydroxyindoleacetic acid (5-HIAA) is observed in urine at $4 \mathrm{~h}$, with levels returning to baseline within $24 \mathrm{~h} .{ }^{8,9}$

These drugs include ondansetron, granisetron, dolasetron and tropisetron. Currently introduced $5 \mathrm{HT}_{3} \mathrm{RA}$ include ramosetron and palonosetron. The antiemetic efficacy of ondansetron has been well established in the prevention and treatment of CINV.

Ramosetron hydrochloride, is a relatively newer $5 \mathrm{HT}_{3}$ receptor antagonist with an affinity higher than ondansetron, granisetron and tropisetron. ${ }^{10}$ Ramosetron has been introduced for the treatment of irritable bowel syndrome (IBS), chemotherapy (cisplatin)-induced nausea and vomiting and late in post-operative nausea and vomiting, with almost no study done for comparing the level of satisfaction of patients receiving this drug with other antiemetics. ${ }^{11-13}$

Patient satisfaction is very important in modern health care system. Though, it is difficult to assess as no golden standard is available, still one of the methods is by using visual analogue scale (VAS) scoring. ${ }^{14}$

Considering the above-mentioned facts and the incidence of CINV, and also that very few comparative studies of ramosetron has been carried out, that too in a western population, the present study was planned to evaluate and compare the level of global satisfaction of patients receiving ramosetron and ondansetron as antiemetics for cisplatin chemotherapy induced nausea and vomiting in treatment of head and neck cancers.

\section{METHODS}

This clinical study was done in collaboration with the department of Radiotherapy and Oncology, SRMSIMS, Bareilly. Patients were recruited in the study according to the subject eligibility

\section{Inclusion criteria}

- Provision of written informed consent.

- Male or female, age $\geq 18$ yrs, with histologically confirmed malignant disease

- Patients naïve to chemotherapy, with a Karnofsky index $\geq 70 \%$

- Scheduled to receive a single dose cisplatin as a single drug or in combination

- Recurrent cases of head and neck cancers, who had taken radiation therapy 6 months back and thus planned for palliative chemotherapy.

- Patients with hepatic function and renal function in normal limits.

\section{Exclusion criteria}

- Inability to understand or cooperate with study procedures.

- Scheduled to receive any drug with antiemetic efficacy from 24 hrs before to 5 days after treatment.

- Emesis, retching, or Grade 2 or 3 nausea $\leq 24 \mathrm{hrs}$ before chemotherapy (Grading of nausea as per the National Cancer Institute Common Toxicity Criteria, version3). ${ }^{14}$

- Ongoing emesis due to any organic etiology.

- Contraindications to 5- $\mathrm{HT}_{3}$ receptor antagonists.

- Patient having $\mathrm{Hb}<9 \mathrm{gm} \%$, TLC <4000/cu.mm and Platelet Count $<1,00,000 /$ cu.mm. in the screening visit.

- Patients on concurrent chemo-radiotherapy were excluded from the study.

\section{Study design}

This was an open-label, randomized, parallel group, prospective and comparative study. The study was performed after the protocol approval by Institutional Ethical Committee.

\section{Study groups}

Depending on the treatment received, there were two study groups.

- Patients were randomized either to the ramosetron group [R] or in the ondansetron group [O] according to the randomization.

- Randomization was done in such a way that eligible patients coming to the OPD were alternately placed in ramosetron group $[\mathrm{R}]$ and ondansetron group [O] respectively.

\section{Study population}

60 diagnosed cases of head and neck cancer, 30 patients in each group were recruited in the study. 6 drop outs were replaced. 


\section{Study conduct}

Brief description of methods/procedures in the study; consenting patients were initially screened for eligibility during any time between day 1 and day 7 . Within 7 days prior to study commencement the following were recorded: physical examination; vital signs; Investigations; past medical history; concomitant medications; and history of nausea and vomiting.

Study visits included clinic visits on day 8, day 9 and day.

Patient diaries were used to record the global satisfaction of patients at particular time based on severity of nausea and vomiting using VAS scale daily until day 12 starting from day 8 (days on which chemotherapy has to be given). On $14^{\text {th }}$ day the Patient Diary Cards were collected back.

Physical examination and vital signs included height and weight, body temperature, blood pressure, heart rate.

\section{Investigations performed}

\section{Screening visit: (Day 1-Day 7)}

At any time point during the week before administration of investigational drugs, patients were screened. History of nausea and vomiting, complete past medical history and physical examination was done and had undergone following tests: haematology, blood chemistry and urine analysis

\section{Study visit (visit 1): (Day 8)}

One hour before the start of chemotherapy, the following parameters were recorded in the enrolled patients: $\mathrm{BP}$ measurement, Heart Rate, Pre-dose Nausea/vomiting, any drug administration, concomitant medications, adverse events recorded.

Patient diary cards were distributed and explained about the relevant entries to be made.

Study visit II: (Day 9)

The following test and procedures were carried on patients on second day after chemotherapy that would mean $9^{\text {th }}$ day of study: physical examination and vital signs, haematology, blood chemistry, urine analysis, adverse adverse events recorded, concomitant medications recorded

\section{Study visit III: (Day - 14)}

The following test and procedures were carried on patients on $14^{\text {th }}$ day of the study. Physical examination and vital signs, haematology, blood chemistry, adverse events recorded, concomitant medications recorded, patient diary cards collected

\section{Study treatment}

- Ramosetron (Nozia) (supplied by Zydus (Alidac Corza) administered intravenously over 30 seconds in the recommended dosage of $0.3 \mathrm{mg}$. It was administered 30 minutes before administration of each course of chemotherapy

- Ondansetron (Osetron), a clear colourless, nonpyrogenic, sterile solution available in $2 \mathrm{ml}$ and $4 \mathrm{ml}$ vials with strength of $2 \mathrm{mg} / \mathrm{ml}$. A total dose equivalent to $16 \mathrm{mg}$ of ondansetron was administered intravenously 30 minutes prior to chemotherapy.

\section{Level of satisfaction assessment}

Visual Analogue scale was plotted to record patients' overall assessment of satisfaction on control of nausea and vomiting. ${ }^{14,15}$

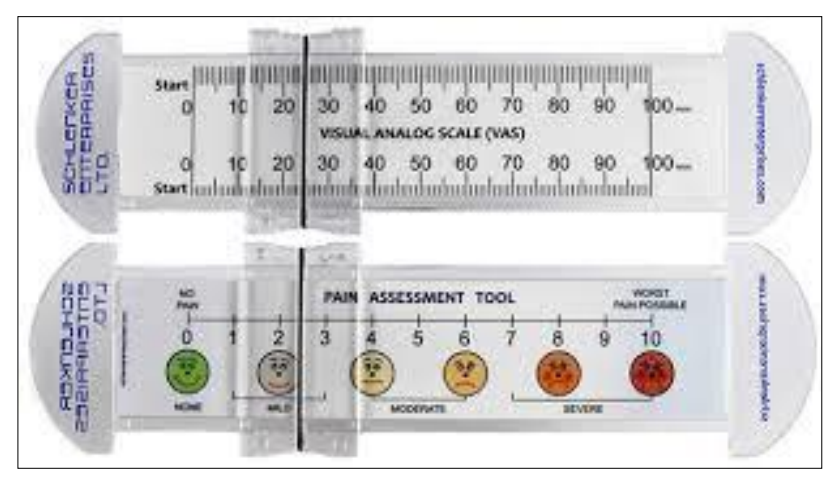

Figure 1: Visual Analogue scale.

\section{Safety assessment}

Safety was assessed by the following: adverse event (AE) reporting for a period of 15 days (30 days for serious AEs); vital sign measurements; laboratory tests performed; physical examination, and electrocardiogram (ECG) recordings performed at specified time points.

\section{Adverse event monitoring}

The expected adverse event for the drugs under consideration as reported in literature are headache, dizziness and constipation with a reported incidence of less than $2 \%$. The adverse events were evaluated as per the Common Terminology Criteria for Adverse Events, version 3.0 (CTCAE). ${ }^{16}$

If any adverse event occurred, it was evaluated by the investigator and recorded in case record form stating the onset, severity, duration, likely cause, action taken reference to the study drugs and outcome.

For all adverse events, the onset, duration, symptoms and sign, treatment, relationship to the study drug were noted in the adverse event page of case record form. 
Serious adverse events (SAE)

These were supposed to be recorded separately in SAE reporting form and reported to IERC/Sponsor immediately of within 24 hours. IERC was supposed to notify the regulatory authority within 14 working days.

\section{Statistical analysis}

The student's ' $t$ ' test (to assess significance in demographic profile between the groups) and $\mathrm{Z}$ test (to observe significance between two proportions) were used to measure the difference among the result, expressed in the form of $\mathrm{P}$ value.

\section{RESULTS}

Table 1: Demographic data and baseline characteristics.

\begin{tabular}{|lll|}
\hline Characteristics & Group O & Group R \\
\hline Age, years (mean \pm SD) & $52.2 \pm 13.38$ & $57.03 \pm 10.80$ \\
\hline Weight, kg (mean \pm SD) & $59.17 \pm 11.66$ & $57.5 \pm 7.84$ \\
\hline Height, cm (mean \pm SD) & $163.4 \pm 9.82$ & $164.7 \pm 9.69$ \\
\hline BSA (mean \pm SD) & $1.46 \pm 0.18$ & $1.44 \pm 0.12$ \\
\hline $\begin{array}{l}\text { Karnofsky index, } \% \\
\text { (mean } \pm \text { SD) }\end{array}$ & $85.33 \pm 5.83$ & $87 \pm 3.05$ \\
\hline Addiction: $\mathrm{n}(\%)$ & & \\
\hline Tobacco addiction & $7(23.33)$ & $11(36.66)$ \\
\hline Smoker & $10(33.33)$ & $11(36.66)$ \\
\hline Alcoholic & $05(16.67)$ & $05(16.67)$ \\
\hline Other & $05(16.67)$ & $04(13.33)$ \\
\hline Nausea and vomiting history: $\mathrm{n}(\%)$ & \\
\hline Present & $05(16.67)$ & $02(6.66)$ \\
\hline Absent & $25(83.33)$ & $28(93.33)$ \\
\hline
\end{tabular}

$\mathrm{n}=$ Number of patients, $(\%)=$ Percentage of patients

\section{Visual analogue scale (VAS) for overall satisfaction}

The demographic data and baseline characteristics of the patients (Table 1) of both the groups were comparable i.e. the difference between the age, weight, height, BSA and Karnofsky index in the patients of two groups was not statistically significant $(\mathrm{P}>0.05)$.

The Difference between the age, weight, height, BSA and Karnofsky index in the patients of two groups was not statistically significant $(\mathrm{P}>0.05)$ by applying student's test.

Nausea and vomiting history: Value of $\mathrm{X}^{2}=1.07$. There was no significant $(\mathrm{P}>0.05)$ association between the history of nausea and vomiting of both the groups by applying chi-square test.

It was observed that VAS score was significantly lower in $\mathrm{R}$ group as compared to $\mathrm{O}$ group $(\mathrm{p}<0.01)$ in acute phase of nausea and vomiting indicating level of satisfaction higher in R group. Similarly, in delayed and overall phase $\mathrm{R}$ group experienced lower range of scoring on VAS scale as compared to $\mathrm{O}$ group. The difference was statistically significant $(\mathrm{p}<0.01)$ (Table 2).

Day 1 results were same as acute phase. On day 2, day 3, day 4 and day $5, \mathrm{R}$ group VAS score were significantly less as compared to $\mathrm{O}$ group $(\mathrm{p}<0.01)$ (Table 3$)$.

The difference between the Phase wise VAS score was highly statistically significant $(\mathrm{P}<0.01)$ for all the phases i.e. acute, delayed and overall phase in favour of $\mathrm{R}$ group.

The difference between the Day wise VAS score was highly statistically significant $(\mathrm{P}<0.01)$ for all the days in favour of ramosetron.

The details of adverse events (whether or not related to the study drug) are shown in Table 4 both ramosetron and ondansetron were well tolerated, and no adverse event related withdrawals were reported during the study.

In the ondansetron group $(53.33 \%)$ of patients and in ramosetron group $(50 \%)$ of patients experienced at least one adverse event.

Table 2: Phase wise VAS for overall satisfaction.

\begin{tabular}{|llllll|}
\hline Phase (time period, hrs) & O group $[$ Mean \pm SD $]$ & R group $[$ Mean \pm SD] & t-value & P-value & Result \\
\hline Acute Phase $(0-24 h)$ & $63.7 \pm 5.06(\mathrm{n}=30)$ & $46.2 \pm 4.95(\mathrm{n}=30)$ & 13.54 & $\mathrm{P}<0.01$ & HS \\
\hline Delayed Phase $(24-120 \mathrm{~h})$ & $63.0 \pm 8.49(\mathrm{n}=120)$ & $49.57 \pm 14.63(\mathrm{n}=120)$ & 8.69 & $\mathrm{P}<0.01$ & HS \\
\hline Overall Phase $(0-120 \mathrm{~h})$ & $63.10 \pm 7.38(\mathrm{n}=150)$ & $48.9 \pm 12.91(\mathrm{n}=150)$ & 11.69 & $\mathrm{P}<0.01$ & HS \\
\hline
\end{tabular}

Table 3: Day wise VAS for overall satisfaction.

\begin{tabular}{|llllll|}
\hline Day (time period, hrs) & O group [Mean \pm SD] & R group [Mean \pm SD] & t-value & P-value & Result \\
\hline Day 1 $(0-24 h)$ & $63.7 \pm 5.06$ & $46.2 \pm 4.95$ & 13.54 & P $<0.01$ & HS \\
\hline Day 2 $(24-48 h)$ & $72.4 \pm 4.55$ & $62.20 \pm 3.96$ & 9.20 & P $<0.01$ & HS \\
\hline Day 3 $(48-72 h)$ & $70.93 \pm 4.47$ & $54.40 \pm 3.67$ & 15.65 & P $<0.01$ & HS \\
\hline Day 4(72-96h) & $66 \pm 3.80$ & $44.8 \pm 3.30$ & 23.07 & P $<0.01$ & HS \\
\hline Day 5 $(96-120 h)$ & $42.7 \pm 3.91$ & $36.90 \pm 4.42$ & 5.38 & P $<0.01$ & HS \\
\hline
\end{tabular}


Most of the adverse events $(81.25 \%)$ in ondansetron group and $(60 \%)$ in ramosetron group were mild in intensity with the majority of adverse events assessed as associated with the patients disease and/or chemotherapy treatment.

The number of patients reporting headache and diarrhea were higher in ramosetron group (14 and 4) as compared to ondansetron group (12 and 2). Whereas, the number of patients reporting dizziness and fatigue were higher in ondansetron group (3 and 2) compared to ramosetron group (0 and 1) respectively.

Overall, the difference in the proportion of patients with patients with possible adverse events was not significant $(\mathrm{P}>0.05)$.

The common adverse events (whether or not related to the study drug) in ramosetron group were headache $(46.66 \%)$, diarrhoea $(13.33 \%)$, fever and abdominal pain $(6.66 \%)$.
Whereas in ondansetron group, the common adverse events were Headache (40\%), Fatigue and diarrhoea $(6.66 \%)$. Constipation and dyspepsia was equal in both the groups $(3.33 \%)$ Tinnitus was present only in $\mathrm{O}$ group $(3.33 \%)$. Fever was less in O group (3.33\%) as compared to R group.

Post hoc analysis reveal no differences in the duration of adverse events commonly associated with $5-\mathrm{HT}_{3}$ receptor antagonist therapy (i.e. headache, fatigue and constipation) in patients treated with ramosetron compared with ondanserton.

No serious adverse event was reported in the study.

No clinically relevant differences were found between both the groups with respect to physical examination, Vital parameters, laboratory parameters i.e. haematology, liver function tests and urine analysis. Overall, no significant safety concerns were identified in the study.

Table 4: Possible adverse events.

\begin{tabular}{|llllll|}
\hline Adverse & O group No. $(\%)$ & R group No. $(\%)$ & ' $Z$ ' value & 'P' value & Result \\
\hline Headache & $12(40)$ & $14(46.66)$ & 0.52 & P $>0.05$ & NS \\
\hline Diarrhoea & $02(6.66)$ & $04(13.33)$ & 0.86 & $\mathrm{P}>0.05$ & $\mathrm{NS}$ \\
\hline Dizziness & $03(10)$ & $00(0)$ & 1.77 & $\mathrm{P}>0.05$ & $\mathrm{NS}$ \\
\hline Fatigue & $02(6.66)$ & $01(3.33)$ & 0.59 & $\mathrm{P}>0.05$ & $\mathrm{NS}$ \\
\hline Constipation & $01(3.33)$ & $01(3.33)$ & 0 & $\mathrm{P}>0.05$ & $\mathrm{NS}$ \\
\hline Tinnitus & $01(3.33)$ & $00(0)$ & 1 & $\mathrm{P}>0.05$ & $\mathrm{NS}$ \\
\hline Fever & $01(3.33)$ & $02(6.66)$ & 0.59 & $\mathrm{P}>0.05$ & $\mathrm{NS}$ \\
\hline Cough & $01(3.33)$ & $01(3.33)$ & 0 & $\mathrm{P}>0.05$ & $\mathrm{NS}$ \\
\hline Asthenia & $00(0)$ & $01(3.33)$ & 1 & $\mathrm{P}>0.05$ & $\mathrm{NS}$ \\
\hline Dyspepsia & $01(3.33)$ & $01(3.33)$ & 0 & $\mathrm{P}>0.05$ & $\mathrm{NS}$ \\
\hline Abdominal Pain & $00(3.33)$ & $02(6.66)$ & 1.43 & $\mathrm{P}>0.05$ & $\mathrm{NS}$ \\
\hline
\end{tabular}

NS - Not significant

After applying ' $\mathrm{Z}$ ' test of difference between two proportions, there is no significant difference $(P>0.05)$ between proportions of possible adverse events in both the groups.

\section{DISCUSSION}

The $5-\mathrm{HT}_{3}$ - receptor antagonist is currently perceived as the gold standard antiemetic treatment providing effective control of acute nausea and vomiting, offering a substantial tolerability benefit over older conventional antiemetic. Ondansetron is the most widely used drug for the prevention of chemotherapy-induced nausea and vomiting. Structure of ramosetron results in more potent blocked of $5 \mathrm{HT}_{3}$ receptor. This effect has been demonstrated both in vitro and in animal studies and in the latter, it appears to prevent vomiting associated with cisplatin chemotherapy. ${ }^{17}$

The efficacy of the ramosetron has been supported by several clinical trials comparing antiemetic efficacy of ramosetron with that of granisetron in 76 patients receiving cisplatin chemotherapy. ${ }^{16}$ Results are strongly in favour of ramosetron.

In some other comparative clinical studies, ramosetron had superior efficacy into the acute and delayed than other first generation $5 \mathrm{HT}_{3}$ receptor antagonist. ${ }^{10,18}$

In the present study, the demographic data and baseline characteristics like age, height and Karnofsky index were comparable with the observations reported by J Jayesh et al and Kim et al except weight which was higher in these studies. $^{13,19}$

In present study patients enrolled were only males. So, we could not make out the gender differences among all characteristics.

Regarding VAS score, highly significant $(\mathrm{p}<0.01)$ results were found in favour of ramosetron starting from day 1 to day 5. Acute, delayed and overall phases also showed highly significant results indicating that level of satisfaction is significantly higher with patients treated 
with ramosetron group as compared to Ondansetron. Similar results were shown by Park et al that is level of satisfaction was higher in ramosetron group as compared to Palonosetron, though it was not statistically significant $(\mathrm{p}>0.05) .{ }^{20}$ Another study revealed no significant difference between level of satisfaction in between two groups $(\mathrm{p}>0.05) .^{21}$

In present study, we could not make out gender differences as far as response of the drugs are concerned. The sample size in the current study was 60 (for both ramosetron and ondansetron) which was less. Hence future studies should be planned with more number of patients considering the limitations in the present study.

\section{Safety}

In present study, hemoglobin, routine blood count and ESR in both the groups were done. They were statistically not significant. Liver function tests, renal function tests, random blood sugar of both the groups which were they were within normal range.

Both the study drugs were well tolerated by al the patients in the study. During the study period, 9 adverse events were reported in both the groups. Study conducted by Jayesh J showed almost same pattern of adverse events i.e. 8 and 5 in ramosetron and ondansetron group respectively suggesting ramosetron as a safer alternative, but the difference was not statistically significant. ${ }^{19}$

Another study done by Shi Y et al concluded ramosetron as safer drug as compared to ondansetronin in terms of controlling appetite loss. ${ }^{22}$ Ramosetron tended to be more effective than ondansetron in its antiemetic action.

In present study, the common adverse events in both the groups (whether or not related to the study drug) were headache, diarrhoea, fatigue, constipation, fever, cough and dyspepsia. Dizziness and tinnitus were reported only in ondansetron group. Abdominal pain and asthenia reported only in ramosetron group. No serious adverse event reported in present study.

Jayesh $\mathbf{J}$ reported bodyache as common adverse event of ramosetron group. ${ }^{18}$ While weakness was common in ondansetron groups. Overall no safety concerns were raised in this study which is consistent with the results other two studies.

\section{CONCLUSION}

Level of global satisfaction (assessed by VAS score) of the patients in ramosetron group was significantly higher as compared to ondansetron group.

Funding: No funding sources Conflict of interest: None declared

Ethical approval: The study was approved by the Institutional Ethics Committee

\section{REFERENCES}

1. Schnell FM. Chemotherapy induced nausea and vomiting: the importance of acute antiemetic control. Oncol. 2002;8:187-98.

2. Coates A, Abraham S, Kaye SB. On the receiving end; patients' perceptions of the side-effects of cancer chemotherapy. Eur J Clin Oncol. 1983;19:203.

3. Grunberg SM, Densen RR, Mavros P, Geling O, Hansen M, Cruciani G, et al. Incidence of chemotherapy induced nausea and emesis after modern antiemetics. Cancer. 2004;100:2261-3.

4. Daum BB, Deuson RR, Mavros P, Hansen M, Herrestedt J. Delayed Nausea and Vomiting Continue to Reduce Patient's Quality of Life after Highly and Moderately Emetogenic Chemotherapy Despite Antiemetic Treatment. J Clin Oncol. 2006;24:4472-8.

5. Andrews PLR, Davis CJ, Bighanis DH, Honvthoin J, Mashell L. The abdominal visceral innervation and the emetic reflex, pathway and plasticity. Can J Physiol Pharmacol. 1990:68:325-45.

6. Habib AS, Gan TJ. Evidence based management of post-operative nausea and vomiting: A review. Can J Anesth. 2004;51:326-41.

7. Berger M, Gray JA, Roth BL Gray R. The expanded biology of serotonin. Ann Rev Med. 2009;60:355-66.

8. Jones AW, Helander A. Time course and reproducibility of urinary excretion profiles of ethanol, methanol, and the ratio of serotonin metabolites after intravenous infusion of ethanol. Alcohol Clin Exp Res. 1999;23(12):1921-6.

9. Janelsins MC, Tejani M, Kamen C, Peoples A, Mustian KM, Morrow GR. Current Pharmacotherapy for Chemotherapy-Induced Nausea and Vomiting in Cancer Patients. Exp Opinion Pharmacotherap. 2013;14(6):757-66.

10. Rabasseda X. Ramosetron, a 5-HT 3 receptor antagonist for the control of nausea and vomiting. Drugs Today. 2002;38:75-89.

11. Hirata T, Keto Y, Funatsu T, Akuzawa S, Sasamata M. Pharmacological profile of ramosetron, a novel therapeutic agent for IBS. Inflammopharmacol. 2007;15(1):5-9.

12. Cheirsilpa A, Sinthusake T, Songsakkaesorn A, Viswaprasit S, Chulaka K, Changkuingdee N. Comparison of ramosetron and granisetron for the prevention of acute and delayed emesis in cisplatin based chemotherapy: A randomized trial. Jpn J Clin Oncol. 2005;35:695-9.

13. Kim MS, Kim DW, Woo SH, Yon JH, Lee S. Effect of ramosetron on shivering during spinal anaesthesia. Korean J Anesthesiol. 2010;58:256-9.

14. Roy BG, Daniel HK, CorneVL, Rene V. The validation of visual analogue scale for patient satisfaction after total hip arthroplasty. Eur Ortho Traumatol. 2012;75(2):1402-7.

15. Tomas C, Pedro AC, Carmen P, Ricardo A, Cesar A, Ali $\mathrm{AB}$ et al. Clinical management, expectations and satisfaction of patients with moderate to severe allergic rhino-conjunctivitis treated with SQ 
standardized grass allergen tablet under routine clinical practice conditions in Spain. Clin Mol Allerg. 2017;15(1):361-7.

16. Colevas AD, Setser A. The NCI Common Terminology Criteria for Adverse Events(CTCAE) v3.0 is the New Standard for Oncology clinical trials. J Clin Oncol. 2004;22:6098.

17. Percie DS, Rudd JA, Adfel CC, Andrews PLR. Cisplatin induced emesis: Systematic review and metaanalysis of the ferret model and the effects of 5HT3 receptor antagonists. Cancer Chemo Pharmacol. 2011;67(3):667-86.

18. Akuzawa S, Ito H, Yamaguchi T. Comparative study of $[3 \mathrm{H}]$ ramosetron and $[3 \mathrm{H}]$ granisetron binding in the cloned human 5-hydroxytryptamine3 receptors. Jpn J Pharmacol. 1998;78:381-4.

19. Sanmukhani JJ, Pawar P, Mittal R. Ramosetron hydrochloride for the prevention of cancer chemotherapy induced nausea and vomiting: The Indian experience. South Asian J Cancer. 2014;3(2):132-7.

20. Park SK, Cho EJ, Kang SH, Lee YJ, Kim DA. A randomized, double-blind study to evaluate the efficacy of ramosetron and palonosetron for prevention of postoperative nausea and vomiting after gynecological laparoscopic surgery. Korean J Anaesthesiol. 2013;64(2):133-7.

21. Piya P, Mungkorn T, Chaivet R, Adisai C. Comparison of Ramosetron with Ondansetron for Prevention of Intrathecal Morphine-Induced Nausea and Vomiting After Primary Total Knee Arthroplasty: A Randomized Control trial. J Arthroplasty. 2017;32(3):1040-3.

22. Shi Y, He X, Yang S, Ai B, Zhang C, Huang T et al. Ramosetron versus ondansetron in the prevention of chemotherapy-induced gastrointestinal side effects: A prospective randomized controlled study. Chemo. 2007;53:44-50.

Cite this article as: Srivastava S, Ahmed QS, Sayedda K. Comparative study of effects of ramosetron and ondansetron on global satisfaction of patients on cisplatin chemotherapy in head and neck cancers. Int J Basic Clin Pharmacol 2018;7:68-74. 